\title{
Evaluation of Food Lures for Capture and Monitoring of Anastrepha fraterculus (Diptera: Tephritidae) on Temperate Fruit Trees
}

\author{
J. M. da Rosa, ${ }^{1,2}$ C. J. Arioli, ${ }^{3}$ J. P. dos Santos, ${ }^{4}$ A. C. Menezes-Netto, ${ }^{5}$ and M. Botton ${ }^{6}$ \\ ${ }^{1}$ Universidade do Estado de Santa Catarina, Laboratório de Entomologia, Lages, SC 88520-000, Brazil (joatanmachado@gmail. \\ com), ${ }^{2}$ Corresponding author, e-mail: joatanmachado@gmail.com, ${ }^{3}$ EPAGRI, Estação Experimental de São Joaquim, Rua João \\ F. Nunes, 102, Jardim Caiçara, São Joaquim, SC 88600-000, Brazil (cristianoarioli@epagri.sc.gov.br), ${ }^{4} E P A G R I$, Estação Experimental \\ de Caçador, Rua Abílio Franco, 1500, Bom Sucesso, Caçador, SC 89500-000, Brazil (janapereira@epagri.sc.gov.br), ${ }^{5}$ EPAGRI, \\ Estação Experimental de Videira, Rua João Zardo, 1660, Campo Experimental, Videira, SC 89560-000, Brazil (alexandrenetto@ \\ epagri.sc.gov.br), and ${ }^{6}$ Embrapa Uva e Vinho, Rua Livramento, 515, Bento Gonçalves, RS 95700-000, Brazil (marcos. \\ botton@embrapa.br),
}

Subject Editor: Charles Burks

Received 14 September 2016; Editorial decision 20 February 2017

\begin{abstract}
The Anastrepha fraterculus (Wiedemann) (Diptera: Tephritidae) is the main pest of fruit trees grown in temperate climates in the southern region of Brazil. The objective of this work was to evaluate the efficiency of the major commercial food lures used in Brazil for trapping and monitoring of $A$. fraterculus in plum, pear, and feijoa orchards. The assessed lures were hydrolyzed proteins of animal origin (CeraTrap) and plant origin (BioAnastrepha), torula yeast + borax (Torula), and grape juice. Response variables included the rate of adult capture (flies per trap per day, FTD) and the percentage of females captured. We also evaluated the number of times the weekly capture rate exceeded the traditional threshold of 0.5 FTD for each lure. Traps baited with grape juice, currently used for monitoring $A$. fraterculus in Southern Brazil, captured fewer adults and a lower percentage of females compared with the other lures. CeraTrap trapped a greater number of $A$. fraterculus adults and, in some cases, a lower percentage of females compared with the other lures in pears. Traps baited with CeraTrap had greater capture rates (FTD), particularly during the stages of fruit maturation and harvest, and even in years with low population density of $A$. fraterculus, thus demonstrating greater sensitivity in the detection of this pest. These results show that, in order to detect and monitor the presence of $A$. fraterculus in plum, feijoa, and pear crops, protein-based lures are superior to grape juice, especially the animal protein CeraTrap.
\end{abstract}

Key words: Anastrepha fraterculus, temperate-zone fruit, monitoring, control index

Many species of Tephritidae are highly polyphagous, and they may become economically important in various fruit trees and host plants (Liu et al. 2013). Brazil is the third largest world producer of fruit, with harvest exceeding 40 million tons per year (Brazilian Fruit Yearbook 2015). The southern region of Brazil is the main producer of temperate-climate fruit, particularly apple (Malus domestica Borkh.), grape (Vitis vinifera L. and Vitis labrusca L.), pear (Pyrus communis L.), peach (Prunus persica L. Batsch), plum (Prunus salicina L.), and feijoa (Acca sellowiana Burret) (Instituto Brasileiro de Geografia e Estatística [IBGE] 2015).

The Anastrepha fraterculus (Wiedemann) (Diptera: Tephritidae) is the main pest of fruit trees grown in temperate climate in Brazil (Nava and Botton 2010). This insect has a neotropical distribution, occurring from the southern United States to northern Argentina
(Malavasi et al. 2000). In Brazil, there are 110 known hosts of $A$. fraterculus. Species of Myrtaceae and Rosaceae families are among the favorites (Zucchi 2008). In a study conducted in the state of Santa Catarina, Garcia and Norrbom (2011) mentioned A. fraterculus presence in 20 plant species, native and exotic, distributed in eight botanical families.

Detection and quantification of fruit fly populations in orchards is a fundamental step for implementing control strategies in integrated pest management (IPM) programs (Scoz et al. 2006, Aluja et al. 2012). The size of the population estimated via trap catch is used as key information for control decisions based on the anticipated level of economic losses (Hickel 2008, Rosa et al. 2013).

The control of fruit flies in fruit trees in Brazilian temperate regions has been conducted mainly with organophosphate insecticides 
to reduce adults and the presence of larvae in fruit. Previous practice has been to treat when the population assessed through McPhail traps reaches an action threshold of 0.5 flies per trap per day or 3.5 flies per trap per week (Kovaleski and Ribeiro 2002, Nora and Hickel 2006, Müller et al. 2013). After the withdrawal of some organophosphate insecticides from the Brazilian market (e.g., fenthion in 2009; Nava and Botton 2010), monitoring this pest became even more important, because the control strategies (e.g., toxic baits, mass trapping) are based mainly on the adults suppression in orchards. Therefore, sensitive and reliable monitoring tools allow improvements in pest control practices with significant reduction of costs (Louw 2013), as it allows reduction in insecticide spraying in total areas.

Monitoring of adult Tephritidae is usually based on the fact that insects need to ingest sugars and proteins to survive and reach sexual maturity, as well as to develop eggs (Aluja et al. 2001). Volatile compounds are therefore the basis for the development of food lures to attract these dipterous pests (Epsky et al. 2014).

In Brazil, monitoring of adult fruit flies of the genus Anastrepha in commercial orchards has been performed with traps containing food lures (Ribeiro 2010), particularly grape juice diluted to $25 \%$ (Kovaleski and Ribeiro 2002) and hydrolyzed protein-based products (Scoz et al. 2006, Rosa et al. 2013, Jahnke et al. 2014), available in the Brazilian market. However, in recent years, there have been significant failures in the control of $A$. fraterculus in several fruit tree species grown in the southern region of Brazil (Nava and Botton 2010). In many cases, oviposition punctures have been detected in fruits still in the early stages of development, even without the capture of adults in the traps lured with these food lures. These failures of control harm adoption of IPM because farmers lose confidence that this monitoring technique adequately detects dangerous populations of A. fraterculus in each crop (Botton et al. 2012).

For these reasons, screening for more effective and reliable lures for monitoring of the pest must be pursued on a crop-by-crop basis in the relevant fruit species, ensuring that trapping rates can match the real population levels of fruit flies that exist in production areas. In the present study, we evaluated the efficiency of commercial food lures used for trapping and monitoring of $A$. fraterculus adults in pear (Pyrus communis L.), plum (Prunus salicina L.), and feijoa (Acca sellowiana Burret) orchards in different regions of the State of Santa Catarina, Brazil.

\section{Materials and Methods}

The study was conducted in plum, pear, and feijoa orchards located in the municipalities of Videira, Caçador, and São Joaquim, respectively, which are important regions for production of temperateclimate fruit in the State of Santa Catarina (Fig. 1). In these regions, fruit farming is one of the main economic activities and the orchards are located in the Atlantic Forest Biome, surrounded by a Mixed Ombrophylous Forest ecosystem, with a significant volume of preserved native woodland.

The evaluated orchards were managed via conventional production systems, with the use of agrochemicals to control arthropod pests, diseases, and weeds (Empresa Brasileira de Pesquisa Agropecuária [EMBRAPA] 2013). The climate of the evaluated areas, according to the Köppen classification, is Cfb, mesothermal, humid, without a dry season, with fresh summers, and annual average temperature of $13.5^{\circ} \mathrm{C}$ in São Joaquim, $15^{\circ} \mathrm{C}$ in Videira, and $16.3^{\circ} \mathrm{C}$ in Caçador. The evaluations were concentrated in periods of fructification of each crop because of low trapping rates in between harvests.

\section{Study Sites}

The plum orchard was located in the municipality of Videira $\left(26^{\circ}\right.$ $59^{\prime} 58.89^{\prime \prime} \mathrm{S}, 051^{\circ} 01^{\prime} 06.50^{\prime \prime} \mathrm{W}$, and $885 \mathrm{~m}$ altitude), in the mesoregion of Alto Vale do Rio do Peixe, in the mid-west of the State (Fig. 1). Evaluation of the traps' contents was carried out weekly between November and February in the harvests of 2012-2013 and 2013-2014, totaling 8 and 10 samples in each season, respectively. The orchard measured $\sim 2.2$ ha and was started $11 \mathrm{yr}$ ago. It is composed of plants of the cultivar 'Letícia', spaced at $6 \mathrm{~m}$ between rows and $4 \mathrm{~m}$ between plants.

The pear orchard was located in the municipality of Caçador $\left(26^{\circ} 51^{\prime} 10.5^{\prime \prime} \mathrm{S}, 50^{\circ} 57^{\prime} 48.9^{\prime \prime} \mathrm{W}\right.$, and $980 \mathrm{~m}$ altitude), also in the mesoregion of Alto Vale do Rio do Peixe (Fig. 1). The experiment was conducted in the 2014-2015 crop season, from October 2014 to April 2015, totaling 20 occasions of samplings. The orchard covers an area of 0.5 ha. It was started $18 \mathrm{yr}$ ago, spaced at $5 \mathrm{~m}$ between rows and $3 \mathrm{~m}$ between plants. The orchard is composed of the Japanese cultivars (Pyrus pyrifolia Nakai var. culta) 'Shinsui,' 'Okusankichi,' 'Shinseiki,' 'Kousui,' 'Housui,' 'Suisei,' 'Nijisseiki,' 'Niitaka,' 'Hakucho,' 'Choujuurou,' 'Kikusui,' 'Hakkou,' and of the Chinese cultivar 'Ya-Li' (Pyrus bretschneideri Rehd.).

The feijoa orchard was located in the municipality of São Joaquim ( $28^{\circ} 17^{\prime} 39^{\prime \prime} \mathrm{S}, 49^{\circ} 55^{\prime} 56^{\prime \prime} \mathrm{W}$, and $1,415 \mathrm{~m}$ altitude), in the mesoregion of Planalto Serrano, in the center-south of the State (Fig. 1). The experiment was conducted in 2014-2015 harvest, between the months of November and April, totaling 22 occasions of samplings. The orchard covers an area of $1.5 \mathrm{ha}$, with $19 \mathrm{yr}$ of age, with plants spaced at $5 \mathrm{~m}$ between rows and $3 \mathrm{~m}$ between plants. The cultivars of the orchard are 'SCS 411-Alcântara,' 'SCS 412Helena,' and 'SCS 414-Mattos e SCS 415-Nonante'.

\section{Lures and Traps}

The evaluated lures were as follows: 1) Hydrolyzed protein of animal origin (CeraTrap, Biolbérica, Barcelona, Spain), undiluted, only with replacement of lost volume by evaporation; 2) Hydrolyzed protein of plant origin (BioAnastrepha, Bio Controle Métodos de Controle de Pragas, São Paulo, Brazil), diluted to $5 \%$; 3) aqueous solution of torula yeast + borax (Torula, Isca Tecnologias, Ijuí, Rio Grande do Sul, Brazil), in the proportion of $18 \mathrm{~g} /$ liter; 4) grape juice (Horti-Fruti Carraro, Rio Grande do Sul, Brazil), 25\%; and distilled water, as a negative control.

The lures were placed in McPhail traps, model Bola PS (Isca Tecnologias), using $300 \mathrm{ml}$ of solution per trap in the plum and feijoa orchards and $500 \mathrm{ml}$ in the pear orchard. The experiment was carried out in a randomized complete block design, with four, four, and five blocks per treatment in feijoa, pear, and plum orchards, respectively. In feijoa (1.5 ha) and plum (2.2 ha) orchards, the distance among replicate blocks (orchard rows) was $30 \mathrm{~m}$, and the distance among treatment plots (traps) within blocks was $20 \mathrm{~m}$. In pear (0.5 ha) orchard, the distance among replicate blocks and the distance among treatment plots within blocks were 10 and $20 \mathrm{~m}$, respectively. The traps were placed in the inner part of the plant canopy, at $1.8 \mathrm{~m}$ above ground level. Insect collection, cleaning of the traps, and sequential rotation were performed every $7 \mathrm{~d}$, together with replacement of lures and refill of the evaporated volume in the treatment with CeraTrap.

\section{Screening and Identification of Insects}

The trapped specimens of fruit flies were separated from the lure solution through a sieve and preserved in $80-\mathrm{ml}$ plastic bottles, containing $70 \%$ alcohol. In the laboratory, the samples were separated 


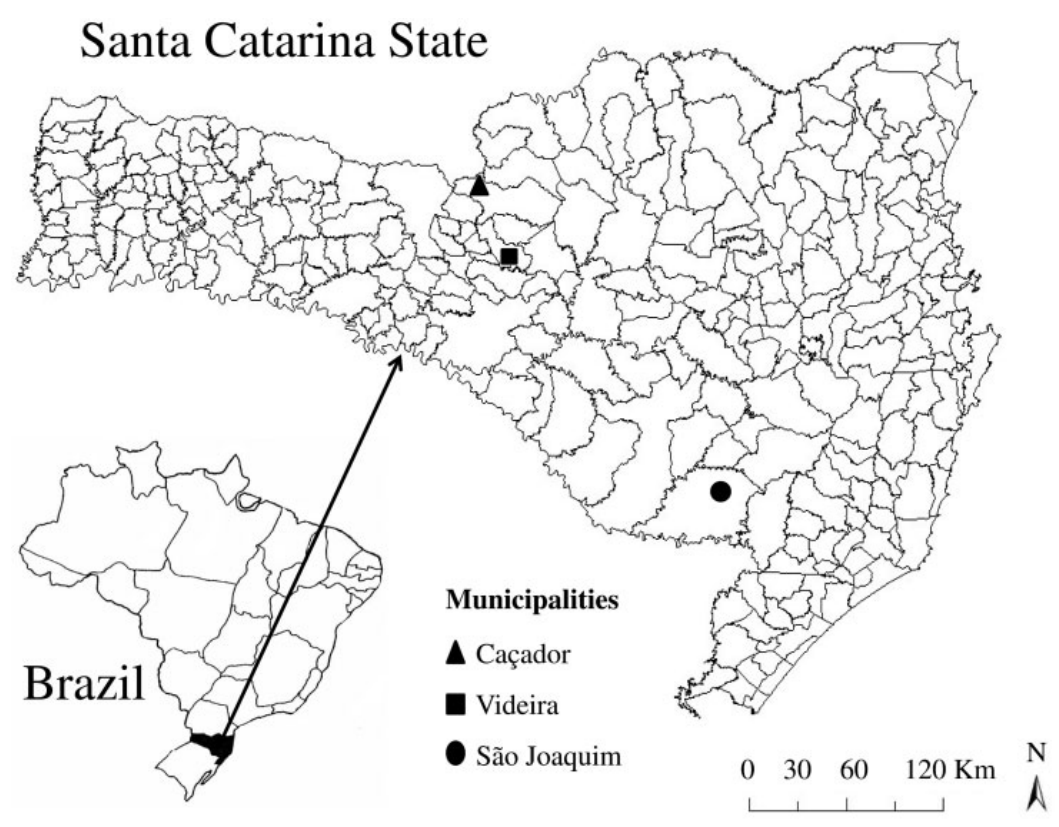

Fig. 1. Location of orchards in the state of Santa Catarina, Brazil. Illustration developed from the cartographic database of the Brazilian Institute of Geography and Statistics.

by sex and identified with the aid of the dichotomous key by Steyskal (1977) and Zucchi (2000). The identification of the species was performed by observation of morphology features of the wing, thorax (wing metanotum and subscutellum), and the ventral surface of the sting, following the methodology of Alberti et al. (2012). The specimens were deposited in entomologic collections of the Experimental Stations of the Agricultural Research and Rural Extension Company of Santa Catarina (Epagri), in the municipalities of Videira, Caçador, and São Joaquim.

\section{Data Analysis}

For the assessment of food lure efficiency, the number of trapped specimens of $A$. fraterculus was calculated by transforming the values into an average of flies per trap per day (FTD). The FTD values were transformed into $\log (\mathrm{y}+1)$, which was determined from the Box-Cox procedure as a transformation necessary to stabilize variance before analysis. For the percentage of females, the assumptions of the model were satisfied. The data were analyzed using ANOVA, and means were compared by Tukey-Kramer HSD test $(P<0.05)$ using the software R (R Development Core Team 2012). In the case of plum, FTD and percentage of female's data, which were obtained in a two-season period, were analyzed by two-way ANOVA model. This analysis revealed there was no significant interaction between treatment and sample period for both FTD $(\mathrm{df}=3,28 ; \quad F=1.49 ; \quad P=0.236)$ and percentage of females $(\mathrm{df}=3,22 ; F=0.46 ; P=0.712)$ variables and, therefore, data from 2012-2013 and 2013-2014 growing seasons were analyzed together. The 'Control' treatment was not considered in ANOVA because there were no fruit flies trapped in this treatment. The average FTD per date per season per host were presented graphically, and number of times the FTD exceeded 0.5 was used as a seasonal comparison of the sensitivity of the lures. The conversion of costs of each lure was calculated based on the rate effective on 18 May 2016 (US Dollar [US\$] to Brazilian Real [R \$] was $\mathrm{US} \$ 1.0=\mathrm{R} \$ 3.56)$.

\section{Results}

\section{Species and Number of Trapped Flies}

In total, 3,549 Tephritid specimens were trapped in the three evaluated regions and harvests. Anastrepha fraterculus represented $98.7 \%$ of specimens trapped in the plum orchard and $100 \%$ of the specimens collected in feijoa and pear orchards. The remaining trapped specimens $(1.3 \%)$ were Anastrepha dissimilis Stone, Anastrepha montei Lima, Rhagoletis blanchardi Aczel, and Blepharoneura sp., which do not have economic importance for the crops in this study. These species were not included in the analyses.

\section{Trapping of $A$. fraterculus in the Plum and Pear Orchards}

In the plum orchard, 748 fruit flies were trapped over two field seasons; 739 of them belonged to the species A. fraterculus: 500 females $(67.7 \%)$ and 239 males $(32.3 \%)$, while in the pear orchard, 2,220 fruit flies were trapped: 1,353 females $(60.9 \%)$ and 867 males $(39.1 \%)$.

The FTD averages from two growing seasons (2012-2013 and 2013-2014) were not significantly different among CeraTrap, BioAnastrepha, and Torula treatments, but these food lures trapped large number of $A$. fraterculus when compared with grape juice and control, in plum orchards (Table 1). Percentage of females did not significantly differ among food lures (Table 2).

In the 2012-2013 season, there was a lower abundance in the pear orchard compared with the following year. The FTD in CeraTrap exceeded the action threshold (i.e., an FTD of $\geq 0.5$ ) two times; first during the preharvest of plum in 10 December 2012 and then on 3 January 2013 (Fig. 2). The lure BioAnastrepha, under the same conditions, reached this index only on 22 January 2013, after the fruit had been harvested.

In 2013-2014, the season with the largest population of the pest, CeraTrap trapped $\sim 3$ times more adults than BioAnastrepha and Torula, and 40 times more than grape juice, in the plum orchard. CeraTrap exceeded the action thresholds seven times, compared with only two times for BioAnastrepha and one time for Torula 
Table 1. Effect of lure type on $A$. fraterculus flies per trap per day (mean and SE) captured in plum, pear, and feijoa orchards

\begin{tabular}{lccc}
\hline Bait & Plum & Pear & Feijoa \\
\hline CeraTrap & $0.33 \pm 0.16 \mathrm{a}$ & $2.95 \pm 1.59 \mathrm{a}$ & $0.40 \pm 0.07$ \\
BioAnastrepha & $0.14 \pm 0.08 \mathrm{a}$ & $0.47 \pm 0.22 \mathrm{~b}$ & $0.17 \pm 0.05$ \\
Torula & $0.09 \pm 0.07 \mathrm{a}$ & $0.20 \pm 0.06 \mathrm{~b}$ & $0.14 \pm 0.06$ \\
Grape juice & $0.06 \pm 0.02 \mathrm{~b}$ & $0.15 \pm 0.07 \mathrm{~b}$ & $0.26 \pm 0.08$ \\
df & 3,28 & 3,9 & 3,9 \\
$F$ (treatment) & 9.69 & 13.44 & 1.47 \\
$P$ (treatment) & $<0.001$ & 0.001 & 0.286 \\
$F$ (replicate block) & 5.60 & 0.89 & 0.39 \\
$P$ (replicate block) & 0.002 & 0.483 & 0.757 \\
\hline
\end{tabular}

Means within the same column followed by different letter are significantly different (experiment-wise $P<0.05$, nontransformed means presented).

Table 2. Effect of lure type on the percentage of females (mean and $\mathrm{SE}$ ) among $A$. fraterculus adults captured in plum, pear, and feijoa orchards

\begin{tabular}{lccc}
\hline Bait & Plum & Pear & Feijoa \\
\hline CeraTrap & $76 \pm 5.0$ & $67 \pm 4.0 \mathrm{a}$ & $51 \pm 3.9$ \\
BioAnastrepha & $65 \pm 8.3$ & $31 \pm 6.2 \mathrm{c}$ & $54 \pm 5.1$ \\
Torula & $89 \pm 2.8$ & $57 \pm 7.3 \mathrm{ab}$ & $55 \pm 4.8$ \\
Grape juice & $63 \pm 6.3$ & $45 \pm 3.1 \mathrm{bc}$ & $53 \pm 6.1$ \\
df & 3,22 & 3,9 & 3,9 \\
$F$ (treatment) & 2.10 & 19.27 & 1.27 \\
$P$ (treatment) & 0.129 & $<0.001$ & 0.342 \\
$F$ (replicate block) & 1.23 & 0.56 & 3.71 \\
$P$ (replicate block) & 0.327 & 0.655 & 0.055 \\
\hline
\end{tabular}

Means within the same column followed by different letter are significantly different (experiment-wise $P<0.05$, nontransformed means presented).

(Fig. 2). Grape juice, in contrast, never exceeded the action threshold in either harvest, even with the presence of the insect in the areas of study detected by other lures.

In the pear crop, the lure CeraTrap showed a higher trapping rate compared with all other lures (Table 1). The average trapping rates of FTD throughout the harvest were $\sim 6,14$, and 19 times higher, respectively, than rates of capture for traps baited with BioAnastrepha, Torula, and grape juice lures (Table 1). BioAnastrepha exceeded the action threshold four times, while Torula and grape juice did so three times (Fig. 2). During the same assessment period, traps baited with CeraTrap lures exceeded the action threshold seven times, thus demonstrating higher attractiveness to fruit flies under the study conditions. Higher percentages of females were detected in traps baited with CeraTrap and Torula; Torula and grape juice did not differ from each other, and BioAnastrepha showed lowest trapping rate of females (Table 2).

\section{Trapping of $A$. fraterculus in the Feijoa Orchard}

In feijoa orchard, the FTD and the percentage of females trapped did not differ among food lures tested (Tables 1 and 2). We observed a ratio of about 1:1 between males and females caught in all the traps. Capture in traps baited with CeraTrap exceeded the action threshold nine times, which was more often than the other lures (Fig. 2). Unlike the findings for the plum and pear sites, in feijoa capture, in traps baited with grape juice exceeded the action threshold more often (five times) compared with traps baited with BioAnastrepha or Torula lures (each exceeded the action threshold two times).

\section{Discussion}

In the south of Brazil, A. fraterculus is the main insect pest in temperate-climate fruit trees like plum (Hickel and Ducroquet 1993), peach (Scoz et al. 2006, Alberti et al. 2009, Reyes et al. 2012), feijoa (Rosa et al. 2013), and pear (Nunes et al. 2013). The use of food lures that are sufficiently attractive to detect $A$. fraterculus presence during critical fruit stages (particularly mature fruit) is crucial for guiding control decisions. Commonly used lures for monitoring $A$. fraterculus in Brazil significantly vary in their patterns of catches and relative attractiveness, which are tied to the plant species and pest phenology (Jahnke et al. 2014, Bortoli et al. 2016).

In plum and pear crops, the first adults of A. fraterculus were trapped at the beginning of November and December, respectively, and there were population peaks in January for both crops (Fig. 2). In pear orchards, this season coincides with the beginning of fruits physiological maturation in Shinsui, Shinseiki, Kousui, Housui, Suisei, and Kikusui cultivars. In mid-February, there was another population peak (Fig. 2), coinciding with the beginning of the fruit maturation in Okusankichi, Nijisseiki, Niitaka, Hakucho, Choujuurou, Hakkou, and Ya-Li cultivars. In the same region, Nora et al. (2000) found two periods of high incidence of Tephritidae in apple orchards (between January and February and between March and April), the latter being associated with the maturation of the cultivars 'Gala' and 'Fuji,' respectively. Garcia et al. (2003), in a peach orchard in the west of the State of Santa Catarina, found that the highest density of $A$. fraterculus occurred in the months of December and January. Given the high incidence of fruit flies in the period of maturation of pears and plums (January and February), monitoring of adults should be continuous and maintained until the harvest of fruits, so as to offer fruit farmers information about the ideal moment for pest control.

Feijoa is more susceptible to A. fraterculus than plum or pear and, in the absence of control measures, losses are potentially higher for this crop (Rosa et al. 2013). The critical periods of incidence of the pest in this crop are the months between February and April (Hickel and Ducroquet 1994, Rosa et al. 2013).

Traps baited with grape juice captured more adults than the other lures investigated in feijoa, but only in the period near feijoa flowering (between December and January). The crop is not susceptible to the attack of A. fraterculus at this phenological stage, as feijoa fruits are still in the beginning of their development (Rosa et al. 2015). However, population fluctuation data can be useful to anticipate measures of population reduction (e.g., use of toxic baits in orchard borders as a physical barrier). Greater levels of captures in flowering stage is probably owing to the absence of matured fruitderived volatile compounds that allowed fruit flies to be attracted to the grape juice lure. From early February until April, the period when crop is vulnerable to losses by fruit flies injuries and the food lures are supposed to have high performance in trapping fruit flies, the capture levels obtained in grape juice baited traps drastically reduced.

During the critical period for feijoa crop (February to April), traps baited with CeraTrap lure exceeded the action threshold six times, compared with only one instance for traps baited with grape juice (Fig. 2). In the pears, there were also more occasions of capture in excess of the action thresholds for traps baited with CeraTrap lure compared with other lures. The action threshold was first exceeded in mid-December in traps baited with CeraTrap lure, but this level of capture was not detected until mid-January in traps baited with grape juice. In pear, the fruits of some cultivars are already under physiological maturation and susceptible to the attack of 

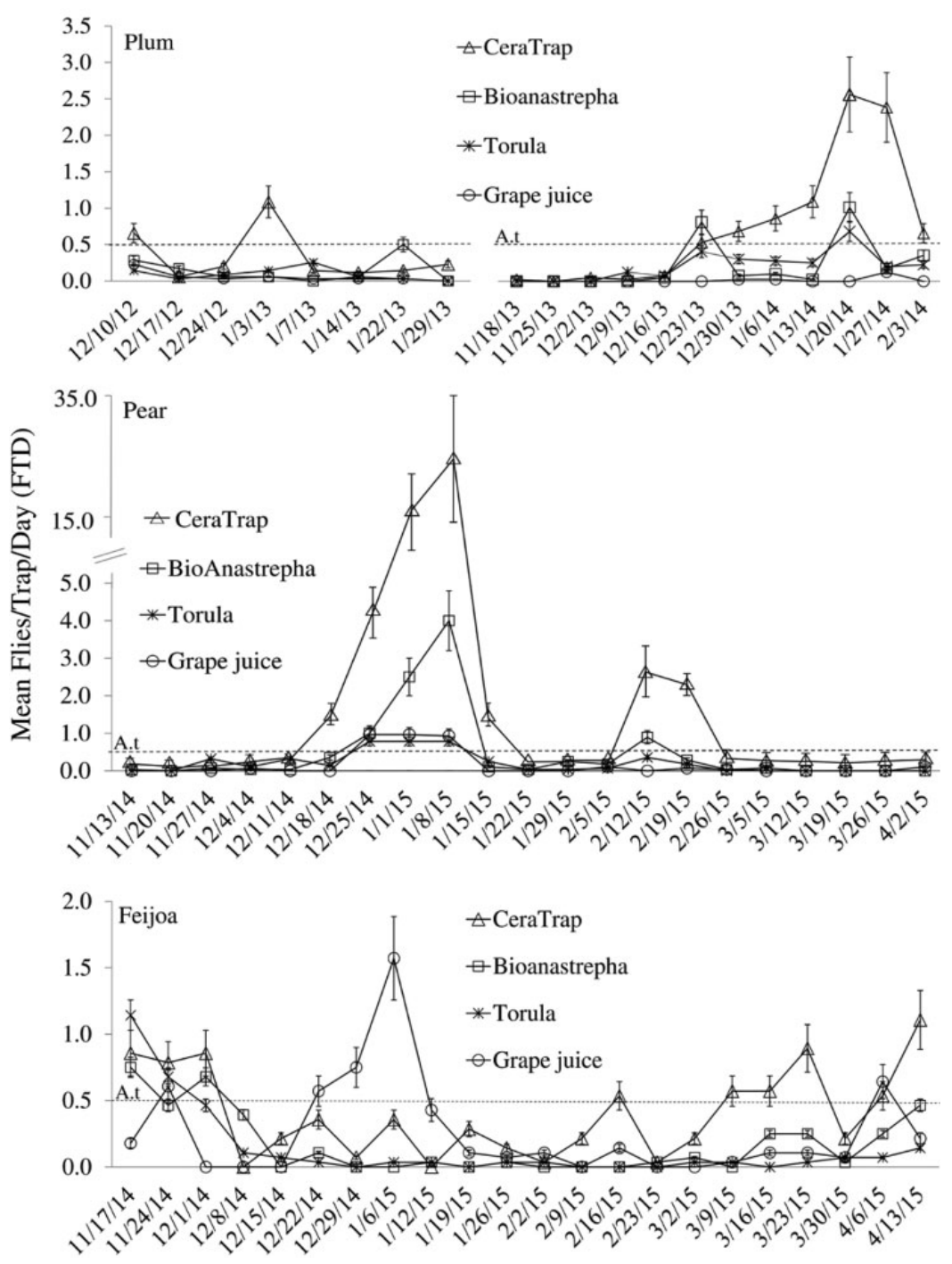

Fig. 2. Mean FTD for A. fraterculus captured in McPhail traps baited with CeraTrap, BioAnastrepha, Torula, and grape juice between $2012-2015$ in plum, pear, and feijoa orchards. A.t: action thresholds.

A. fraterculus by mid-December. Thus, in this period, monitoring failures can compromise yield. Likewise, in the plum orchard, traps baited with grape juice did not exceed the action threshold in a 2-yr period of evaluation, although the presence of the species was detected in the other assessed lures (Fig. 2).

These data indicate that traps baited with the CeraTrap lure performed better relative to other lures during the development phase of the fruits and close to the harvest period. These phenological phases of temperate-climate fruit trees in Brazil are critical periods to maintain $A$. fraterculus populations below the level of economic losses, as this species is polyphagous and readily oviposits in host fruit. In contrast to traps baited with CeraTrap lure, the rates of capture for traps baited with grape juice were often greatest during the flowering stage or at the beginning of fruit development. However, larvae of flies of the genus Anastrepha usually do not develop in these phenological phases of the hosts, because of the presence of lethal oils in the epidermis or chemical substances that act as food inhibitors (Calkins and Malavasi 1995), or because of greater stiffness of the epidermis, making them not preferential for oviposition (Hickel and Ducroquet 1994).
Several studies have examined the effect of food lures on A. fraterculus in southern Brazil (Raga et al. 2006, Scoz et al. 2006, Nunes et al. 2013, and Bortoli et al. 2016). These studies showed variability between the results, even when the same formulations are compared in orchards of the same fruit species. Several factors could be responsible for this variation. One possible factor is lack of standardization of industrial manufacture of lures (Scoz et al. 2006, Teixeira et al. 2010), as the majority of the formulations are composed of inputs of vegetable origin (derived from maize and fruit), which may change depending on the growing season. A second possible factor is the age of lures used in the tests. Mangan and Thomas (2014) stated that grape juice starts the fermentation process quickly, generating an unpleasant smell. To avoid that, Epsky et al. (2015) suggest the addition of preservatives, which can also change the conditions of lures and, thus, influence the production of volatile compounds and the attractiveness of the formulations to insects (Castrejón-Gómez et al. 2004, Epsky et al. 2015). A third possible factor is competition of odors inside orchards, between the fruits and the lures, mainly during the stage of fruit maturation (Cornelius et al. 2000, López-Guillén et al. 2010, and Jahnke et al. 2014). According to Cornelius et al. (2000), the presence of volatile 
compounds of maturing fruits may affect the chemotactic behavior of fruit flies, which influences not only the search of the host for oviposition and consequent survival of offspring, but also in the identification of lures, such as those present in monitoring traps. Hickel and Ducroquet (1994) found that the odor released by maturing feijoa fruits was important to attract and maintain the flies within the orchard, as in this period the average number recorded was 5.0 FTD, which was reduced to zero after fruit harvest.

Whole grape juice diluted to $25 \%$ has been recommended as a standard food lure for the capture of fruit flies in apple orchards in Brazil (Kovaleski and Ribeiro 2002, Ribeiro 2010). With the recognized importance of this lure for the monitoring of $A$. fraterculus in this crop, its use has been extended for plum, pear, peach, and feijoa crops, which are crops often grown together with apple, as alternative sources of income, and in which A. fraterculus is also considered as a major pest.

Grape juice did not capture as many adults as other lures in plum and pear crops in this study. Similarly, Epsky et al. (2015) found that aqueous grape juice is a poor lure to trap the Caribbean fruit fly Anastrepha suspensa (Loew) in guava (Psidium guajava L.) orchards. The hydrolyzed protein BioAnastrepha and torula yeast were less attractive than CeraTrap in pear orchard and more attractive than grape juice in plum orchard, similar to results obtained in apple (Teixeira et al. 2010) and citrus (Bortoli et al. 2016).

Grape juice lures are still often used by fruit growers for monitoring $A$. fraterculus in orchards of southern Brazil, although they are not recommended in crops such as peach (Scoz et al. 2006), grape (Zart et al. 2011), apple (Teixeira et al. 2010), and common guava, P. guajava (Reyes 2011). According to Teixeira et al. (2010), the preference for the use of this lure by fruit growers is mainly because it is easy to obtain and has low cost (US\$0.84 ha $\mathrm{h}^{-1} \mathrm{wk}^{-1}$ ) of monitoring compared with other lures available in the market (Torula US\$1.21 ha $\mathrm{hk}^{-1}$ and CeraTrap US\$1.47 $\mathrm{ha}^{-1} \mathrm{wk}^{-1}$ ). CeraTrap has a higher cost than the tools mentioned above because it is a liquid formulation and it is still imported to Brazil, which increases its final cost. This is a disadvantage compared with Torula, which are compacted pellets, lighter and, thus, cheaper.

In this study, the hydrolyzed protein CeraTrap was found to be the most efficient of the lures examined for monitoring of $A$. fraterculus populations in pear crop in southern Brazil. Furthermore, this lure detected more action thresholds levels and, more important, these threshold detections occurred in critical stages of potential economic injury levels caused by A. fraterculus. Herrera et al. (2015) and Lasa et al. (2015), in Mexico, also confirmed the superiority of CeraTrap for monitoring Anastrepha ludens (Loew) in citrus, and Anastrepha obliqua (Macquart) and Anastrepha serpentina (Wiedemann) in mango trees. These authors also found that CeraTrap attracts fewer nontarget organisms and is stable, lasting up to 3 mo (Lasa et al. 2014). These results indicate that this hydrolyzed protein lure shows promise for improving monitoring for $A$. fraterculus in the southern region of Brazil. The finding in this study that CeraTrap captures as many or more females as other lures suggests that it could also be used to develop attract-and-kill control strategies.

\section{Acknowledgments}

We thank Jorge Alexandre Borges (technician) for helping with field experiments; Dr. Simone S. Werner for assisting us with data analysis; Geraldo Gaio (fruit grower) for allowing access to his plum experimental area; Brazilian Innovation Agency (FINEP project 223/2010), Rio Grande do Sul Research Foundation (FAPERGS), and National Counsel of Technological and
Scientific Development (CNPq), for supporting this research; and the contributions made by two anonymous reviewers on early version of manuscript that significantly improved its quality. We hereby declare no conflicts of interest with regards to the commercial products evaluated.

\section{References Cited}

Alberti, S., F.R.M. Garcia, and G. M. Bogus. 2009. Moscas-das-frutas em pomares de pessegueiro e maracujazeiro, no município de Iraceminha, Santa Catarina, Brasil. Ciênc. Rural 39: 1565-1568.

Alberti, S., G. M. Bogus, and F.R.M. Garcia. 2012. Flutuação populacional de moscas-das-frutas (Diptera, Tephritidae) em pomares de pessegueiro e maracujazeiro em Iraceminha, Santa Catarina. Rev. Biotemas 25: 53-58.

Aluja, M., F. Díaz-Fleischer, D. R. Papaj, G. Lagunes, and J. Sivinski. 2001. Effects of age, diet, female density, and the host resource on egg load in Anastrepha ludens and Anastrepha obliqua (Diptera: Tephritidae). J. Insect Physiol. 47: 975-988.

Aluja, M., M. Ordano, L. Guillén, and J. Rull. 2012. Understanding long-term fruit fly (Diptera: Tephritidae) population dynamics: Implications for area wide management. J. Econ. Entomol. 105: 823-836.

Bortoli, L. C., R. Machota Jr., F.R.M. Garcia, and M. Botton. 2016 Evaluation of food lures for fruit flies (Diptera: Tephritidae) captured in a citrus orchard of the Serra Gaúcha. Fla. Entomol. 99: 381-384.

Botton, M., R. Machota Jr., D. E. Nava, and C. J. Arioli. 2012. Novas alternativas para o monitoramento e controle de Anastrepha fraterculus (Wied., 1830) (Diptera: Tephritidae) na fruticultura de clima temperado, pp. 1-14. In Proceedings, 22th Congresso Brasileiro de Fruticultura, 22-26 October 2012, Bento Gonçalves, RS. Sociedade Brasileira de Fruticultura, Bento Gonçalves, RS.

Brazilian Fruit Yearbook. 2015. Production. Editora Gazeta, Santa Cruz do Sul, RS, Brazil.

Calkins, C. O., and A. Malavasi. 1995. Biology and control of fruit flies (Anastrepha) in tropical and temperate fruit. Rev. Bras. Frutic. 17: 36-45.

Castrejón-Gómez, V. R., M. Aluja, R. Arzuffi, and P. Villa. 2004. Two lowcost food attractants for capturing Toxotrypana curvicauda (Diptera: Tephritidae) in the field. J. Econ. Entomol. 97: 310-315.

Cornelius, M. L., J. J. Duan, and R. H. Messing. 2000. Volatile host fruit odors as attractants for the oriental fruit fly (Diptera: Tephritidae). J. Econ. Entomol. 93: 93-100.

(EMBRAPA) Empresa Brasileira de Pesquisa Agropecuária. 2013. Produção Integrada de maçã. Grade de agroquímicos. (http://www.cnpuv.embrapa. br/tecnologias/pim/grade_agroquimicos_2013-2014.pdf) (accessed 14 November 2016).

Epsky, N. D., P. E. Kendra, and E. Q. Schnell. 2014. History and development of food-based attractants, pp. 75-118. In T. E. Shelly, N. D. Epsky, E. B. Jang, J. Reyes-Flores, and R. I. Vargas (eds.), Trapping and the detection, control, and regulation of tephritid fruit flies: lures, area-wide programs, and trade implications. Springer, Dordrecht, The Netherlands.

Epsky, N. D., M. A. Gill, and R. L. Mangan. 2015. Grape juice as a bait for Anastrepha suspensa (Diptera: Tephritidae) and Zaprionus indianus (Diptera: Drosophilidae). J. Econ. Entomol. 108: 2065-2073.

Garcia F.R.M., and A. L. Norrbom. 2011. Tephritoid flies (Diptera, Tephritoidea) and their plant hosts from the state of Santa Catarina in southern Brazil. Fla. Entomol. 94: 151-157.

Garcia, F.R.M., J. V. Campos, and E. Corseuil. 2003. Flutuação populacional de Anastrepha fraterculus (Wiedemann, 1830) (Diptera, Tephritidae) na região Oeste de Santa Catarina, Brasil. Rev. Bras. Entomol. 47: 415-420.

Herrera, F., E. Miranda, E. Gómez, E. Presa-Parra, and R. Lasa. 2015. Comparison of hydrolyzed protein baits and various grape juice products as attractants for Anastrepha Fruit Flies (Diptera: Tephritidae). J. Econ. Entomol. 109: 161-166.

Hickel, E. R. 2008. Pragas das fruteiras de clima temperado no Brasil: Guia para o manejo integrado de pragas. Epagri, Florianópolis, SC, Brazil.

Hickel, E. R., and J.P.H. J. Ducroquet. 1993. Flutuação populacional de espécies de Anastrepha (Diptera: Tephritidae) relacionada com a fenologia de frutificação de pêssego e ameixa em Santa Catarina. An. Soc. Entomol. Bras. 22: 591-596. 
Hickel, E. R., and J.P.H.J. Ducroquet. 1994. Ocorrência de mosca-das-frutas Anastrepha fraterculus (Wied.) em frutas de goiabeira-serrana. An. Soc. Entomol. Bras. 23: 311-315.

(IBGE) Instituto Brasileiro de Geografia e Estatística. 2015. Banco de dados agregados: Sistema IBGE de Recuperação Automática. (http://www. cidades.ibge.gov.br/xtras/home.php) (accessed 16 December 2015).

Jahnke S. M., C. Reyes, and L. R. Redaelli. 2014. Influência da fase de maturação de pêssegos e goiabas na atratividade de iscas para Anastrepha fraterculus. Cient 42: 134-142.

Kovaleski, A., and L. G. Ribeiro. 2002. Manejo de pragas na produção integrada de maçã. Bento Gonçalves: Embrapa Uva e Vinho. 8p (Technical circular $\left.n^{\circ} 34\right)$.

Lasa, R., Y. Toxtega, F. Herrera, A. Cruz, M. A. Navarrete, and S. Antonio. 2014. Inexpensive traps for use in mass trapping Anastrepha ludens (Diptera: Tephritidae). Fla. Entomol. 97: 1123-1130.

Lasa, R., F. Herrera, E. Miranda, E. Gómez, S. Antonio, and M. Aluja. 2015. Economic and highly effective trap-lure combination to monitor the Mexican fruit fly (Diptera: Tephritidae) at the orchard level. J. Econ. Entomol. 108: 1637-1645.

Liu, X., Y. Jin, and H. Ye. 2013. Recent spread and climatic ecological niche of the invasive guava fruit fly, Bactrocera correcta, in mainland China. J. Pest Sci. 86: 449-458.

López-Guillén, G., J. Toledo, and J. C. Rojas. 2010. Response of Anastrepha obliqua (Diptera: Tephritidae) to fruit odors and protein-based lures in field trials. Fla. Entomol. 93: 317-318.

Louw, C. E. 2013. The efficacy of traps in predicting fruit fly infestation levels in mango orchards. Acta Hortic. 992: 429-439.

Malavasi, A., R. A. Zucchi, and R. L. Sugayama. 2000. Biogeografia, pp. 93-98. In A. Malavasi and R. A. Zucchi (eds.), Moscas-das-frutas de importância econômica no Brasil: Conhecimento básico e aplicado. Holos, Ribeirão Preto, SP, Brazil.

Mangan, R. L., and D. B. Thomas. 2014. Comparison of torula yeast and various grape juice products as attractants for Mexican fruit fly (Diptera: Tephritidae). J. Econ. Entomol. 107: 591-600.

Müller, C., C. J. Arioli, F. A. Mascaro, M. Botton, and J.R.S. Lopes. 2013. Pragas da ameixeira no Brasil. pp. 69-110. In L. Rufato, T. R. Pelizza and A. A. Kretzschmar (eds.), A cultura da ameixeira. Udesc, Florianópolis, SC, Brazil.

Nava, D. E., and M. Botton. 2010. Bioecologia e controle de Anastrepha fraterculus e Ceratitis capitata em pessegueiro, p. 29. Pelotas, Embrapa Clima Temperado. (Documents n ${ }^{\circ}$ 315).

Nora, I., and E. R. Hickel. 2006. Pragas da macieira: Dípteros e lepidópteros, pp. 463-486. In Epagri (ed.), A cultura da macieira. Epagri, Florianópolis, SC, Brazil.

Nora, I., E. R. Hickel, and H. F. Prando. 2000. Moscas-das-frutas nos estados brasileiros: Santa Catarina, pp. 271-276. In A. Malavasi and R. A. Zucchi (eds.), Moscas-das-frutas de importância econômica no Brasil: Conhecimento básico e aplicado. Holos, Ribeirão Preto, SP, Brazil.

Nunes, M. Z., R. S. Santos, M.I.C. Boff, and J. M. Rosa. 2013. Avaliação de atrativos alimentares na captura de Anastrepha fraterculus (Wiedemann, 1830) (Diptera: Tephritidae) em pomar de macieira. Rev. Fac. Agron. 112: 91-96.

Raga, A., R. A. Machado, W. Dinardo, and P. C. Strikis. 2006. Eficácia de atrativos alimentares na captura de moscas-das-frutas em pomar de citros. Bragantia 65: 337-345.

Reyes, C. P. 2011. Monitoramento de Anastrepha fraterculus (Wied. 1980) (Diptera: Tephritidae): Flutuação populacional, avaliação de atrativos e caracterização ovariana. M.S. thesis, Universidade do Rio Grande do Sul, Porto Alegre.

Reyes, C. P., S. M. Jahnke, and L. R. Redaelli. 2012. Caracterização ovariana e definição do número de gerações de mosca-das-frutas sul-americana durante o ciclo das culturas em dois pomares na região de Porto Alegre, RS, Brasil. Arq. Inst. Biol. 79: 185-192.

R Development Core Team. 2012. R: A language and environment for statistical computing. R Foundation for Statistical Computing, Vienna, Austria.

Ribeiro, L. G. 2010. Manejo das principais pragas da macieira no Brasil. Agropecu. Catarin. 23: 149-157.

Rosa, J. M. da, M.I.C. Boff, P. A. Gonçalves, P. Boff, and M. Z. Nunes. 2013. Andiroba oil (Carapa guianensis Aubl) in the capture of the fruit fly (Anastrepha fraterculus Wiedemann) in feijoa (Acca sellowiana (Berg) Burret). Idesia 31: 97-101.

Rosa, J. M. da, M.I.C. Boff, M. Z. Nunes, L. Agostinetto, and P. Boff. 2015. Damage caused by Conotrachelus psidii (Coleoptera: Curculionidae) to the fruits of feijoa (Acca sellowiana). Rev. Colomb. Entomol. 41: 12-17.

Scoz, P. L., M. Botton, M. S. Garcia, and P. L Pastori. 2006. Avaliação de atrativos alimentares e armadilhas para o monitoramento de Anastrepha fraterculus (Wiedemann, 1830) (Diptera: Tephritidae) na cultura do pessegueiro (Prunus persica (L.) Batsh). Idesia 24: 7-13.

Steyskal, G. C. 1977. Pictorial key to species of the genus Anastrepha (Diptera: Tephritidae). (Special Publication) Entomological Society of Washington, Washington, DC.

Teixeira, R., L. G. Ribeiro, M.I.C. Boff, P. Boff, and O. Z. Zanardi. 2010. Atratividade de iscas alimentares comerciais para mosca-das-frutas em pomar de macieira. Agropec. Catarin. 23: 84-88.

Zart, M., M. Botton, and O. A. Fernandes. 2011. Injúrias causadas por mosca-das-frutas sulamericana em cultivares de videira. Bragantia 70: 64-71.

Zucchi, R. A. 2000. Taxonomia, pp. 13-24. In A. Malavasi and R. A. Zucchi (eds.), Moscas-das-frutas de importância econômica no Brasil: Conhecimento básico e aplicado. Holos, Ribeirão Preto, SP, Brazil.

Zucchi, R. A. 2008. Fruit flies in Brazil: Anastrepha species, their host plants and parasitoids. (http://www.lea.esalq.usp.br/anastrepha) 